\title{
Н.В. Соколова
}

\section{«... А ДРУГУЮ КРОШКУ ВЗЯТЬ В МИР» (О ФУНКЦИЯХ КРЕСТЬЯНСКОЙ ОБЩИНЫ В ПЕРВОЙ ЧЕТВЕРТИ XVIII В.)}

Аннотация Статья посвящена изучению важнейших функций общины. Анализ контекстно-зависимых значений лексемы «крошка» и определение содержания данного понятия в источниках, касающихся крестьянского землепользования и тяглого обложения в монастырской деревне Центра России, показали повсеместное сохранение в практике первой четверти XVIII в. системы вытного тягла. Констатируется значимая роль мирского самоуправления в определении принципов, организационных форм и механизмов раскладки тягла и наделении крестьян пашенной землей и прочими угодьями.

Ключевые слова: налоги, община, крестьянское самоуправление, административно-хозяйственная функция, финансово-фискальная функция.

Summary The article is devoted to the study of the most important functions of obschina. The analysis of the «kroshka» lexeme's context-dependent meanings and the definition of this concept in the sources related to peasant land use and taxation in the monastic village of Central Russia has demonstrated the widespread preservation of the vytnoye tyaglo tax allocation system in practice of the first quarter of the 18th century. The article states the significant role of community self-government in determining the principles, organizational forms and mechanisms of tax allocation and allotting peasants with arable and other land.

Keywords: taxes, obschina, peasant self-government, administrative and land allocation function, financial and fiscal function.

В источниках конца XVII - первой четверти XVIII в. из архивов монастырей Центральной России лексема «крошка» встречается в связи с различными ситуациями, касающимися крестьянского землепользования и тяглого обложения. Так, в «Книгах старосты мирскова Семена Титова 
приемных мирским денгам, что с которой выти принято» (1696-1697 гг.), сохранившихся среди документов приписной к московскому Донскому монастырю Медведевой пустыни в Дмитровском уезде среди прочего помечено: «Перваго гривеннаго збору... Запазинские выти у десяцкова Федора Добычи с 18 полуосмаков с крошкой принято 1 руб. 31 алт. 4 д., ... Чернеивские выти у десяцкого Семенки Любимова с 14 полуосмаков с крошкой принято 1 руб. 15 алт.» ${ }^{1}$. Очевидно, что речь идет о некоем превышении тягла, указанного в «полуосмаках». Однако в ставшей уже хрестоматийной статье А.Л. Шапиро, который особо отмечал многообразие терминов, применявшихся для обозначения единиц тяглого обложения, и привел довольно-таки длинный их перечень - выть или ее доли, «кость», «рубль», «алтын», «деньга», «десятина» и т.д., «крошка» не упомянута². Значения, отвечающего приведенному выше контексту, нет ни в «Словаре русского языка XVIII века», ни в «Словаре русского языка XI-XVII вв.»³.

Целью статьи является изучение контекстно-зависимых значений данной лексемы, определение содержания понятия «крошка» в документах, касающихся различных сторон функционирования общины и мирского самоуправления в монастырских вотчинах в первой четверти XVIII в. Весьма информативным источником для решения вытекающих из такого целеполагания задач является рукопись, включающая в качестве главного документа мирскую окладную книгу вотчины Медведевой пустыни 1718 г. ${ }^{4}$ История ее возникновения вкратце такова. 29 июля 1718 г. житенный староста Минеевской выти Андрей Федосеев и крестьяне деревень Тишина, Прокохова, Назарова и Исакова подали в московский Донской монастырь челобитную. По их утверждению, крестьяне входивших в ту же всевотчинную общину деревень Новое село, Липина, Ступина, Борцова, Маншина, Куминова и Карамышева, сложив с себя тягло, продолжают владеть земельными наделами. Челобитчики просили их «с вышеписанными деревнями в тяглой земле, и в сенных покосах, и во всяких угодьях и их же братья крестьян поверстать в равенстве» ${ }^{5}$.

Результатом крестьянского обращения стал указ монастырских властей о проведении подворного описания, по итогам которого надлежало «тягла

1 ОПИ ГИМ. Ф. 440. Оп. 1. Д. 447. Л. 18-19.

2 Шапиро А.Л. Переход от повытной к повенечной системе обложения крестьян владельческими повинностями // Ежегодник по аграрной истории Восточной Европы. 1960 год. Киев, 1962. С. 207.

${ }^{3}$ Словарь русского языка XI-XVII вв. Вып. 8. Крада - Лящина. М., 1981. С. 77; Словарь русского языка XVIII века. Вып. 11. Крепость - Льняной. СПб., 2000. С. 36-38.

${ }^{4}$ ЦГА Москвы. Ф. 421. Оп. 1. Д. 551.

5 Там же. Л. 1, 1 об. 
их крестьянские пустые меж ими поверстать в жило». Для проведения тяглого обложения («для окладу») предписывалось привлечь «вотчинных лутчих и постоянных и правдивых крестьян, что пристойно» ${ }^{6}$. В тексте окладных книг они неоднократно названы «выборными окладчиками», что позволяет думать, что они были избраны общиной на мирском сходе Выборность «окладчиков» подтверждает и текст скрепы на включенном в данную рукопись мирском приговоре об утверждении нового оклада от 3 августа 1718 г.: «К сему приговору монастыря Медведевы пустыни подьячей Иван Садыков вместо старосты, и соцкого, и выборных окладчиков, кои имена писаны в сем приговоре, по их велению руку приложил» ${ }^{8}$.

Следует подчеркнуть, что в источнике прямо указано, что мирские выборные из «лутчих и постоянных и правдивых крестьян» не только производили оклад, но и присутствовали на предварявшем его подворном описании: «И при оных крестьянех досматривано и переписывано» ${ }^{9}$. Их участие подтверждается и скрепой по листам рукописи: «К сим книгам села Раменок поп Федор вместо старосты Ивана Иванова, и соцкого Андрея Емельянова, и окладчиков Лазаря Алфериева, Симеона Амвросиива, Василия Силина с товарыщи по их прошению руку приложил». В скрепе перечислены три «выборных окладчика», однако в рукописи содержится и полный их перечень, в который включено 20 имен с указанием места проживания. В составе окладной комиссии были представлены 10,4\% дворохозяйств и 60,6\% поселений данного всевотчинного «мира», что, безусловно, означало высокую степень ее осведомленности о тяглоспособности крестьянских хозяйств.

По распоряжению монастырских властей к проведению описания вотчины были привлечены монастырские приказчики и подьячие. Их имена зафиксированы в скрепах по листам рукописи: «К сим книгам Донского монастыря подьячей Григорей Гоминицкий руку приложил»; «К сим книгам монастыря Медведевы пустыни подьячей Иван Садыков вместо себя

6 Там же. Л. 1 об.

7 О выборных приговорах мирских сходов на «окладчиков» см., например: Соколова Н.B. Община в монастырской деревне Центра России в начале XVIII в. (К вопросу о поземельно-хозяйственной функции крестьянского мира) // Ежегодник по аграрной истории Восточной Европы. 2012 год: Типология и особенности регионального агарного развития России и Восточной Европы X-XXI вв. М.; Брянск, 2012. С. 94-100; Соколова Н.В. Окладные книги как источник для изучения социальных микроструктур нижегородской монастырской деревни 60-90-х гг. XVII в. // Лествица: Материалы научной конференции по проблемам источниковедения и историографии памяти В.П. Макарихина. Нижегородский государственный университет (22 мая 2003 г.). Н. Новгород, 2005. С. 218-221.

8 ЦГА Москвы. Ф. 421. Оп. 1. Д. 551. Л. 53-53 об.

9 Там же. Л. 3. 
и вместо прикащиков Сидора Максимова и Федора Осетрова руку приложил». Судя по почерку второй скрепы, сохранившийся беловик окладных книг писал тот же Иван Садыков. Скрепы нанесены на нижнее поле листов и заканчиваются на л. 151, после итоговых данных по сельцу Васнево. Далее в рукописи следуют общие итоги тяглого обложения, а также мирской приговор от 3 августа 1718 г. и приговор соборных старцев Донского монастыря, которыми результаты оклада были утверждены. Приговор монастырского собора имеет рукоприкладство архимандрита Донского монастыря Лаврентия. Многократно повторенная на боковом поле всей рукописи скрепа «Донского монастыря казначей монах Варлаам», по-видимому, была нанесена перед отправкой окладных книг из Донского монастыря наместнику Медведевой пустыни. Отвез рукопись 30 ноября 1718 г. крестьянин монастырской деревни Липина Федор Иванов ${ }^{10}$.

Хорошая сохранность и прозрачность всей истории происхождения источника позволяют, исследовав его методами внешней и внутренней критики, сделать вывод о высокой степени достоверности содержания документа. Окладные книги представляют собой совокупность описаний всех существовавших на тот момент поселений монастырской вотчины. Каждая из 33 рубрик состоит из вводной формулы с названием села, сельца или деревни, подворных записей и итогового текста. Анализ показал, что записи, относящиеся к отдельному дворохозяйству, составлены с соблюдением определенного формуляра. Начальная статья включает имя дворовладельца, его возраст и семейное положение (женат, вдов), имена братьев, сыновей, внуков, племянников, зятьев, пасынков - с указанием их возраста и, для достигших брачного возраста, семейного положения (женат, холост), а в необходимых случаях - индивидуальных особенностей, прежде всего касающихся их трудоспособности, которые, по-видимому, учитывались при окладе («хвор», «ногами увечен», «хвор ногами и вдов», «крив», «глух», «слеп»). Наиболее информативна и разнообразна по содержанию следующая статья, которая представляет собой запись сказки дворовладельца о тягле, прежнем и нынешнем, о причинах, по которым оно было «збавлено», о наличии/отсутствии соответствующего решения общины или монастырских властей. В завершающей части зафиксировано содержание принятого выборными окладчиками приговора о новом окладе, иногда - какие-то особые его условия, решение о предоставленной льготе, о необходимости раздела двора и т. п.

10 54-летний сын дворовладельца Ивана Миронова (Там же. Л. 11). 
Посвященный тому или иному поселению итоговый текст содержит сопоставление общего тягла по крестьянской «скаске» и по новому окладу («Итого в вышеписанной деревне Быкова явствует по скаске их Прокофия с товарыщи 5 полуосмака прежнего тягла. А по нынешнему новому окладу в той деревне тягла пять же полуосмаков» ${ }^{11}$; «Итого в вышеявленной деревне Куминовой явствует по скаске их, Афонасия с товарыщи, 4 полуосмака прежнего тягла. А по нынешнему новому окладу в той деревне 3 полуосмака без полукрошки. А за тем окладом в остатках полуосмак с полукрошкою» ${ }^{12}$ ).

$$
* * *
$$

В первой четверти XVIII в. во владениях Медведевой пустыни в Дмитровском уезде за единицу тягла был принят «полуосмак». Так, в приходных книгах всевотчинного старосты Лариона Моисеева под датой 26 октября 1700 г. записан сбор «в ямские и полоняничные денги по 6 алтынов по 4 денги с полуосмака», а под 28 марта 1701 г. - сбор «по 3 алтына по 2 денги с полуосмака в сенные государевы копенные денги» ${ }^{13}$. В 1718 г. «полуосмак» оставался самой крупной единицей тягла. В итоговых записях по поселениям составители окладных книг «полуосмаки» суммируют, но никогда не переводят в более крупные единицы («Итого в помянутой деревне Прокоховой явствует по скаске их, Григорья с товарыщи, четыре полуосмака прежнего тягла. А по нынешнему новому окладу в той деревне 4 полуосмака»; «Итого в вышеявленной деревне Борцово явствует по скаске их, Патрекея с товарыщи, тринатцать полуосмаков прежнего тягла. А по нынешнему новому окладу в той деревне тягла осмь полуосмаков бес трети. За тем окладом в остатке пять полуосмаков с третью» ${ }^{14}$. Несмотря на явную генетическую связь существующей системы тяглого обложения с традиционной вытной, в источнике не фигурируют ни «выть», ни «осмак».

В качестве дворового тягла «полуосмак» встречается редко, а крестьянские хозяйства, тягло которых превышает данное значение, - единичны. Большинство дворов живет на тягле, которое представляет собой ту или иную долю полуосмака. В частности, распространенным было тягло $1 / 3$ и 2/3 полуосмака. Для обозначения более мелкой доли тягла в данной общине использовали редко встречающуюся лексему «шестырка», значение которой, впрочем, расшифровывается в самих окладных книгах: «Да ис пустовытной доли владеют шестою долькою полуосмака тое ж доли, что жил

\footnotetext{
${ }^{11}$ Там же. Л. 33 об.

12 Там же. Л. 25 об.

${ }^{13}$ ОПИ ГИМ. Ф. 440. Оп. 1. Д. 447. Л. 87-89.

${ }^{14}$ ЦГА Москвы. Ф. 421. Оп. 1. Д. 551. Л. 13 об., 31.
} 
Иван Ларионов. А ныне приговорили выборные окладчики быть им впредь на крошке, а шестырку пустовытную взять в мир» ${ }^{15}$.

В источнике немало дворов с тяглом «крошка». В самом простом случае оно составляло «крошку» по предыдущему тяглому обложению и не изменилось в результате нового оклада. К таким хозяйствам относится, например, двор Тимофея Осипова из деревни Быкова. Согласно «скаске» 37-летнего дворовладельца, имевшего на момент описания маленького сына и неженатого 15-летнего брата, «тягла де под ним крошка прежнего окладу». Оценив тяглоспособность двора, мирские выборные оставили тягло прежним: «А ныне приговорили выборные окладчики быть ему на крошке ж» ${ }^{16}$.

Однако, для того чтобы определить, что скрывается под лексемой «крошка», нам придется обратиться к анализу фрагментов с более сложным контентом. В силу указанных выше причин для немалого числа дворов тягло по предыдущему окладу, тягло на момент начала описания и вновь определенное выборными окладчиками тягло - это разные величины. Данное обстоятельство позволяет выяснить содержание понятия «крошка», прибегнув к простым и интуитивно понятным расчетам. Так, живущий в селе Раменье 52-летний Иван Андреев (во дворе также записан его 20-летний зять) сказал выборным окладчикам, что «тягла де под ним крошка. А в прошлых годех было у него тягла полосмака. И ис того де прежнего тягла збавил с себя крошку в прошлом 706 году по умертвии брата своего» ${ }^{17}$. Таким образом, из текста следует, что «полуосмак» в данной общине состоял из двух «крошек». Немного более сложный «пример на дроби» в случае с тяглом Савелия Тарасова (65 лет) из деревни Мишуково подтверждает, что «крошка» рассматриваемого источника равна $1 / 2$ полуосмака (или, условно, 1/32 выти): «А сказал тягла де под ним крошка. А в прошлых годех было у него тягла полосмака без трети. И ис того прежнего тягла в прошлом 715 году збавил шестую дольку полуосмака самоволием. И та де збавочная земля за ним же по прежнему») ${ }^{18}$.

К такому же выводу приводит анализ итоговых статей, в которых отражен результат деятельности выборных окладчиков. Например, в сельце Пантелеево на момент описания было всего два двора - Михаила Анисимова (65 лет) и Петра Анисимова (49 лет). В книгах записан приговор окладной комиссии: «А ныне приговорили выборные окладчики быть им, Михаилу з братом Петром, на полуосмаке по крошке обоим в равенстве.

\footnotetext{
15 Там же. Л. 7.

${ }^{16}$ Там же. Л. 33.

17 Там же. Л. 26 об.

${ }^{18}$ Там же. Л. 9.
} 
Итого в помянутом селце явствует по скаске их, Михаила с товарыщи, полосмака прежнего тягла. А по нынешнему новому окладу в том селце полосмака ж» ${ }^{19}$. В другом поселении зафиксирована ситуация, когда мирским выборным не удалось полностью распределить прежнее тягло на имеющиеся 3 двора: «Итого в вышепомянутой деревне Русанова явствует по скаске их, Василия с товарыщи, два полосмака. А по нынешнему окладу в той деревне тягла полосмака с крошкою. За тем окладом в остатке крошка» ${ }^{20}$.

В некоторых монастырских деревнях «крошка» оказалась самым распространенным тяглом (в деревне Русанова — это 3 из 3 дворов, в деревне Липина - 3 из 4, в деревне Прокохова - 6 из 7). Например, на таком тягле сидели два Михаила из деревни Русанова, имевшие дополнительных работников в лице 15-летних неженатых сыновей. Михаил Агеев (59 лет, всего во дворе 5 д. м. п.) в 1716 г. был переведен из деревни Исакова на тягло умершего крестьянина Филипа Антропова («А сказал тягла под ним крошка... А сверх де оного тягла пашни и сенных покосов за ним во владении нет. А ныне приговорили выборные окладчики быть ему на старом тягле на одной крошке») $)^{21}$. Михаил Алексеев (49 лет, всего во дворе 3 д. м. п.) пришел на выморочное тягло двумя годами позже: «А сказал тягла де под ним с нынешнего 718 году во взятье крошка ис пустоты без оржаного и без ярового севу после умершего крестьянина Костянтина Федорова». В ходе нового оклада «приговорили выборные окладчики быть ему на крошке и льготы дать ему на год в податях и во всяком монастырском зделье как с той доли будет питатца хлебом, а прошед год велеть ему все отправять с крошки» ${ }^{22}$. Однако в источнике описаны дворы и на тягле вдвое меньшем - «полукрошке», т. е. 1/4 «полуосмака». Так, в деревне Дятловка, которая, похоже, восстанавливалась после периода запустения, оба двора записаны на «полукрошке». Таково ж было тягло 2 из 5 дворов, например, в деревнях Федоровка, Тишина, Ступина.

В источнике не называются критерии, которыми руководствовались окладчики при определении дворового тягла. В историографии неоднократно отмечалось, что трудовые ресурсы крестьянского хозяйства являлись важнейшим, но далеко не единственным фактором ${ }^{23}$. В этом контексте обратим внимание на «скаску» 50-летнего Григория Дмитриева из дерев-

${ }^{19}$ Там же. Л. 7 об.

${ }^{20}$ Там же. Л. 5 об.

${ }^{21}$ Там же. Л. 5.

${ }^{22}$ Там же. Л. 5 об.

${ }^{23}$ См., например: Горская Н.A. Монастырские крестьяне Центральной России в XVII в. М., 1977. С. 26-32; Назаров В.Д., Тихонов Ю.А. Крестьянский и бобыльский двор в светских владениях центральных уездов I половины XVII в. // История СССР. 1977. № 4. С. 152-162; Соколова Н.В. Окладные книги как источник... С. 221-228; Соколова Н.В. Социальные 
ни Федоровка: «А в прошлых де годех было под ним тягла полкрошки, а в 714 году положено на него тягла крошка, и с тое де накладной полкрошки он, Григорей, с помянутого 714 году пашню по нынешней 718 год не пахал и сена не косил. А ныне приговорили выборные окладчики быть ему на крошке». При этом мирские выборные особо отметили в окладных книгах, что до 1 сентября 1719 г. он платит с полкрошки, а затем - с крошки. Настойчивость крестьянского мира в увеличении тягла данного двора, по-видимому, означает, что потенциальные ресурсы хозяйства были обусловлены не только количеством мужчин - полных работников (дворовладелец имел сыновей 14, 10 и 7 лет), но и какими-то другими обстоятельствами ${ }^{24}$.

Иная ситуация сложилась в хозяйстве крестьянина той же деревни 67-летнего Леонтия Степанова, с которым жили его сыновья 12, 7 и 4 лет. Согласно его «скаске», «тягла де под ним полкрошки. А в прошлых де годех было у него треть полуосмака, а с прошлого 713 году ис того тягла збавил от взятья сына своего в матрозы... А ныне приговорили выборные окладчики быть ему на трети впредь, а подати с него брать с полукрошки по 720 год за сущею ево скудостью, а с оного году брать с трети» ${ }^{25}$. Таким образом, в данном случае выборные окладчики вернули двору тягло в 1/3 полуосмака, а следовательно, и землю, что важно с учетом числа едоков, возраста дворовладельца и его детей, и предоставили более длительную льготу в податях — «за сущею ево скудостью».

Живущая в деревне Дрочева солдатка Аксинья Федоровская жена Никифорова, единственным мужчиной-работником во дворе которой был 14-летний сын, сообщила мирским выборным, что «тягла под нею полкрошки да четверть крошки. А податей де не платит». Окладчики приговорили «быть ей на полукрошке, а подати брать с четверть крошки прошед два года, а 3 другой не брать еще два года» ${ }^{26}$. В крестьянской «скаске» жителя сельца Васнево Якова Афонасьева сообщается, что его тягло - «полкрошки бес трети». Это самое маленькое тягло по «скаскам». Однако ниже в тексте зафиксировано, что «збавочная» треть полукрошки «с прошлого 713 году

микроструктуры монастырской деревни в Центральной России конца XVII - первой четверти XVIII в. (Некоторые источники и методы исследования) // Северо-Запад в аграрной истории России: Межвузовский тематический сборник научных трудов. Калининград, 2005. С. 15-17; Черкасова М.С. Зажиточные крестьяне Троице-Сергиева монастыря в конце XVI - XVII в.: тягло, наделы, денежная рента // Зажиточное крестьянство России в исторической ретроспективе. Материалы XXVII сессии Симпозиума по аграрной истории Восточной Европы. Вологда, 2001. С. 76-77.

${ }^{24}$ ЦГА Москвы. Ф. 421. Оп. 1. Д. 551. Л. 6.

${ }^{25}$ Там же. Л. 6 об.-7.

${ }^{26}$ Там же. Л. 19 об. 
за ним же во владении», т. е. фактически он продолжал пользоваться всей землей, приходившейся на $1 / 2$ «крошки» ${ }^{27}$.

Следует подчеркнуть, что упоминания более мелких долей «крошки» $1 / 3,1 / 4,1 / 6$ и 1/8 - встречаются обычно при описании тягла, снятого с себя крестьянами, или, наоборот, принятой на себя части тягла другого двора или из «пустовытных» земель. Например, 45-летний крестьянин из деревни Ступина Матвей Иванов сказал, что «тягла де под ним полкрошки да четверть крошки. А в прошлых де годех было у него тягла крошка. Ис того прежнего окладу збавил он с себя четверть крошки в прошлом 716 году, как помре дядя ево Семион Аристов да взят сын у него в салдаты. А ныне же оная збавочная четверть за ним же во владении» ${ }^{28}$. Крестьянских дворов на тягле 1/4 крошки, т. е. 1/8 полуосмака или, в терминологии источника, «осмушка», в данной общине нет. Но таково льготное тягло, с которого после нового оклада должна платить, например, вдова Анна Семенова дочь из села Чернеево. Согласно ее «скаске», «тягла де под нею крошка, податей не платит с прошлаго 710 году от взятья дву сынов своих в салдаты да по умертвии мужа своего». Выборные окладчики приговорили «быть ей на полукрошке, а подати брать с осмушки, а з другой осмушки не брать два года» ${ }^{29}$.

«Связь вытного обложения с земельным наделом, - отмечал А.Л. Шапиро, - привела к запутанности в терминологии, ибо вытью называли то окладную единицу, то тот или иной участок земли, с которого крестьяне тянули вытное тягло» ${ }^{30}$. Наглядной иллюстрацией справедливости этого наблюдения и для иных единиц тяглого обложения является запись о дворе Макара Федорова (деревня Борцова). В ней лексемой «крошка» обозначены и тягло по «прежнему» и по новому окладу, и то, что можно вспахать «под оржаной сев», т. е. земля («А сказал тягла де под ним крошка прежнего окладу, да ис пустых де доль за ним же, Макаром, во владенье прошлых лет полосы по две и по три в поле пустой крошки. А нынешнего 718 году под оржаной сев вспахал де всю крошку. А ныне приговорили выборные окладчики быть ему на одной крошке, а другую взять в мир») $)^{31}$. Практически как равнозначные выступают понятия «покидочное тягло» и «збавочная земля» в описании хозяйства Матвея Никитина (село Чернеево): «А сказал тягла де под ним полкрошки, а в прошлых де годех было под ним тягла полосмака.

\footnotetext{
27 Там же. Л. 49 об.-50.

28 Там же. Л. 14 об.

29 Там же. Л. 45 об.

${ }^{30}$ Шапиро А.Л. Переход от повытной к повенечной системе обложения... С. 208.

${ }^{31}$ ЦГА Москвы. Ф. 421. ОП. 1. Д. 551. Л. 30 об.
} 
И ис того де числа збавил с себя крошку да полкрошки. И тою де збавочною землею владеет он же, Матвей. Да ис того же покидочного тягла сосед ево Влас посеял в прошлом 717 году рожью одну полосу полуосмашную да в пару нынешнего 718 году вспахал одну ж полосу» ${ }^{32}$.

В деревне Маншина окладчики определили для 70-летнего Кондратия Варфоломеева, с которым живет семья его 20-летнего зятя (дети мужского пола у обоих, похоже, отсутствовали), быть «на трети полуосмака, а пахать крошку два года, а прошед два года подати брать с крошки» ${ }^{33}$. Иными словами, данное хозяйство обложено тяглом в $1 / 3$ «полуосмака» и с него два года следует платить подати, но «пахать» Кондратий с зятем будут больший надел, соответствующий $1 / 2$ полуосмака («крошка»). Данная лексема используется также с глаголом «владеть» или в составе формулы «во владение в распашку», как, например, в записи о хозяйстве Изота Иванова из сельца Васнево: «А сказал тягло де определено ему с нынешнего 718 году крошка пустовытная во владение в распашку. А ныне приговорили выборные окладчики и всем миром владеть ему крошкою, а податей с него и монастырского всякого изделья не спрашивать с него три года, пакамест распашет и завод возмет. А прошед оные годы брать с него с крошки» ${ }^{34}$. Фактически прямое отождествление «прибавочной полкрошки» с землей и пашенным наделом обнаруживаем в описании двора Леонтия Васильева из деревни Короваева, которому по новому окладу определено быть «на полуосмаке с полукрошкою... А оная прибавочная полкрошки взять им в той же деревне у салдатки Авдотьи Васильевской жены для того, что оная земля надлежит быть к их тяглой пашне смежна» ${ }^{35}$.

Необходимо остановиться особо на понятии «рыбачья крошка». Оно встречается в источнике лишь однажды, в итоговой записи по деревне Косилова: «Итого в оной деревне Косилове с пустошью Сорокиным полосмака с крошкою. Ис того числа рыбачья крошка без податей». Объяснение находим в описании двора 70-летнего Федора Осипова, с которым жил 27-летний сын и два маленьких внука: «А сказал тягла де под ним крошка прежнего окладу, збавки нет. А вместо де податей отправляет в монастырь рыбную ловлю. А ныне приговорили выборные окладчики быть ему по-прежнему» ${ }^{36}$. При этом рубрика имеет стандартное начало: «Деревня Косилова, а в ней крестьян». Впрочем, появление такого двора именно

\footnotetext{
${ }^{32}$ Там же. Л. 42 об.

33 Там же. Л. 34 об.

${ }^{34}$ Там же. Л. 50.

${ }^{35}$ Там же. Л. 36 об.

${ }^{36}$ Там же. Л. 39.
} 
в данной деревне неслучайно, поскольку это расположенное на берегу реки Сестры поселение - ближайшее к монастырю.

Согласно окладным книгам 1718 г., такое же тягло — «крошку» — имели все 8 дворов подмонастырской слободы, где жили служебники, рыбаки и квасовары. Составителями документа во всех случаях использована стандартная формула: «А сказал тягла де под ним крошка прежнего окладу» ${ }^{37}$. Однако условия, на которых монастырские «служебники» пользовались своими земельными наделами, принципиально отличаются от крестьянских: «И оныя де рыбаки и квасовары с тех помянутых тягл податей не платят. А вместо податей отправляют в монастыре: рыбаки рыбу ловят, а квасовары квасы и пива варят, и огороды пашут, и сторожу они ж отправляют, переменяясь по два человека понедельно». Тем не менее слобода не просто формально включена в окладные книги. Согласно представлениям сельского мира, служебники хозяйствуют на волостной земле, потому в книгах записано: «А ныне выборные окладчики и всем миром приговорили быть им по-прежнему» ${ }^{38}$.

Точно так же - с упоминанием не только выборных окладчиков, но и «всего мира» - в книгах записано о выделении земли отставным драгунам в селе Чернеево: «Ис тех остаточных пустых тягл приговорили выборные окладчики и всем миром отставным драгуну Стахию Никифорову владеть бес податей треть полуосмаком, на пропитание с маткою и с сиротами, которая треть осталась при долке у Марка з братом, да драгуну Родиону Заваруеву приговорили владеть бес податей же четверть крошки на пропитание, которая прилична к тяглу Ивана Дементьева» ${ }^{39}$. Как и в приведенном выше эпизоде оклада в деревне Короваева, связанном с передачей «полкрошки» от солдатки Авдотьи Тимофеевой дочери Васильевской жены Захарова, в тексте указано, где именно находится земля, которую следует отдать отставным драгунам. Как представляется, это важная деталь, свидетельствующая о том, что за новым тяглым обложением в данном случае не последуют всеобщая мера земли и ее всеобъемлющее перераспределение, т. е. полный земельный передел.

«Общественный дуализм» общины ${ }^{40}$, которая, с одной стороны, являлась защитником интересов сельского мира in corpore, a с другой - выступала в качестве инструмента фискальной политики государства и землевладельца, отчетливо проявлялся в механизмах, выработанных ею с целью выпол-

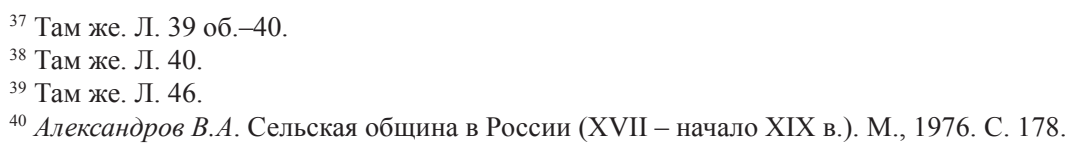


нения важнейших функций по организации крестьянского землепользования и тяглого обложения. Одним из таких механизмов была практика частичных «поравнений» тягла (и, соответственно, земли), подобных тому, что нашел отражение в окладных книгах 1718 г. При этом речь не шла об уравнении хозяйственного положения членов сельского или волостного мира, в том числе обеспеченности их основным средством производства землей. Принцип уравнительности применительно к русской общине рассматриваемого периода следует понимать как уравнение соотношения между трудовыми и хозяйственными ресурсами крестьянского двора и его тяглом (и, соответственно, земельным наделом). Именно с возвращением к общепринятой норме связаны приговоры выборных окладчиков о передаче тем или иным двором тягла и земли «в мир», в том числе и вынесенный в заголовок данной статьи, с упоминанием «крошки» («А ныне приговорили выборные окладчики быть ему на крошке. А другую крошку взять в мир»; «А ныне приговорили выборные окладчики быть ему на крошке. А протчую землю взять в мир» $\left.{ }^{41}\right)$. В тексте мирского приговора от 3 августа 1718 г. содержится важное положение, призванное в условиях круговой поруки защитить интересы всей общины: «А ежели кто из них, крестьян, против нынешнего окладу тягла своего самоволием своим збавит, и с таких складчиков имать пени монастырской в мир, что власти укажут, и чинить жестокое наказание» ${ }^{42}$. Соборные старцы Донского монастыря в своем приговоре не только установили процедуру отказа от тягла или его части, но и определили размер пени, предписав впредь со «сбавленного самоволием» тягла подати брать «вдвое» ${ }^{43}$.

Традиционность крестьянской общины и мирского самоуправления в монастырских вотчинах Центральной России в первой четверти XVIII в. бесспорна. Причины сходства — как основных общинных практик, так и на уровне понятийного аппарата — в вотчинах различных монастырей, относящихся к разным уездам, могут быть предметом особого исследования ${ }^{44}$. В частности, лексема «крошка» использовалась для обозначения некоей доли вытного тягла в документах различной территориальной и владельческой принадлежности.

${ }^{41}$ ЦГА Москвы. Ф. 421. Оп. 1. Д. 551. Л. 25, 25 об.

${ }^{42}$ Там же. Л. 53 об.

${ }^{43}$ Там же. Л. 52.

${ }^{44}$ Соколова Н.В. Община в монастырской деревне Центра России... С. 91-105; Соколова Н.В. Окладные книги как источник... С. 217-228; Соколова Н.В. Роль крестьянской общины в системе налогово-повинностных практик XVII - первой четверти XVIII в. (на материалах монастырских вотчин Центральной России) // Ежегодник по аграрной истории Восточной Европы. 2014 год. Фискальная политика и налогово-повинностные практики в аграрной истории России X-XXI вв. М.; Самара, 2015. С. 65-76. 
Так, в подворной росписи тягла от 16 июня 1702 г. из архива Переславского Федоровского женского монастыря среди прочего упоминается и «крошка»: «В первой полувыти Григорей Федоров с товарыщи. У Григорья тягла осмак с крошкою. У Назара Андреева тягла осмак с крошкою. У Степана Прокофьева $з$ братьями ево с Иванком Большим и с Иванком Меньшим тягла у них осмак с крошкою. У Якима Михайлова з братом ево Андроном тягла у них осмак. В другой полувыти 3 другонатцаткою Кирило Иванов с товарыщи. У Кирила тягла осмак. У Калины Лукьянова другонатцатка с крошкою. У Бориса Микитина тягла осмак бес крошки» ${ }^{45}$. Типичные записи дворового тягла крестьян деревни Потанина того же корпоративного земельного собственника от июня 1703 г. выглядят следующим образом: «У Прокофья Устинова 2 сына, тягла осмак бес крошки», «У Алексея Медведева сын, у него ж зять, тягла осмак бес крошки») ${ }^{46}$.

Сохранилась челобитная 1699 г., поданная крестьянином той же деревни Потанина Иваном Петровым, о сложении им тягла «в мир»: «А я сирота, человек немолодой, а тягло подо мною, сиротою, большое, осмак, и мне, сироте, одному ныне и старому, того осмака держать и тягла с нево тянуть никоими делы невмоч». Как следует из текста, один его женатый сын умер, другой («и с женой») - лежат при смерти, поэтому он просит снять с него тягла крошку, а ему оставить три крошки («против моей мочи»). Прошение было удовлетворено: «207-го году маия в 7 день Данилова монастыря отец архимандрит Варфоломей, слушав сий челобитной, приказал Федоровского девичья монастыря строителю старцу Дорофею, буде можно, деревни Потанина у крестьянина Ивашка Петрова снять тягло четверть осмака в мир, а ему, Ивашку з детми, жить на трех четвертях осмака» ${ }^{47}$. Можно констатировать, что в данной вотчине, во-первых, содержание понятий «крошка» и «четверть осмака» тождественны, во-вторых, «крошка» здесь, как и в вотчине Медведевой пустыни в Дмитровском уезде, равна 1/32 выти, хотя за единицу тягла принят «осмак», а не «полуосмак».

В источниках, которые отражают результаты земельного передела, произведенного крестьянами данной монастырской вотчины в 1703-1704 гг., зафиксировано использование в том же контексте лексемы «кроха»: «Деревни Лусниковы вновь тягла прибавлено осмак с полукрохою. Деревни Пешкова вновь тягла прибавлено полтора осмака и полкрохи. Деревни Тощебулова вновь тягла прибавлено два осмака без полуторы крохи. Деревни Самкова вновь тягла прибавлено полтора осмака с крохою. Деревни Гулина

\footnotetext{
${ }^{45}$ Архив СПбИИ РАН. Колл. 102. Картон 7. Д. 34.

${ }^{46}$ Там же. Д. 223, 241.

${ }^{47}$ Там же. Картон 6. Д. 13.
} 
вновь тягла прибавлено четверуха без двух крох. Деревни Петриловы вновь тягла прибавлено полтора осмака» ${ }^{48}$.

Использование лексемы «кроха» также выявлено в источниках крестьянского происхождения, возникших в вотчинах Иосифо-Волоколамского монастыря. В приговор мирского схода, состоявшегося 13 сентября 1721 г. в селе Новое, входившем в заопределенную вотчину монастыря в Рузском уезде, включена, вероятно, для удобства сборщиков, подробная роспись норм вытных платежей «на майскую треть в рублевой збор, что збираетца в разные приказные платежи»: «И... приговорили с той вотчины со крестьян собрать с выти по 16 руб., с полувыти по 8 руб., з дву осмаков по 4 руб., с осмака по 2 руб., с полуосмака по 1 руб., с крохи по 16 алт. по 4 ден.». Очевидно, что «кроха» здесь также представляла собой $1 / 2$ «полуосмака» или $1 / 4$ «осмака». В другом мирском приговоре той же общины, от 19 ноября 1721 г., дополнительно указан сбор с «полукрохи»: «И в оной платеж приговорили с вышеписанной вотчины со крестьян собрать с вытного тегла по 12 руб. с выти, с полувыти по 6 руб., з дву осмаков по 3 руб., с осмака по 1 руб. по 16 алт. 4 ден., с полуосмака по 25 алт., с крохи по 12 алт. по 3 ден., с полукрохи по 6 алт. по пол 2 ден.» ${ }^{49}$. По итогам произведенного на мирском сходе «разруба» («по мирской роскладке и по заручному приговору») осуществлялся сбор денег с поселений данного сельского «мира». Так, в «Книге приходной Рузского уезда вотчины Иосифова монастыря села Нового зборщика Ивана Семенова» 1722 г. отмечено поступление денег с деревень, совокупное тягло которых описано с использованием лексемы «кроха»: «Деревни Медветкова с семи крох февраля в 21 день принято у Ивана Данилова рубль шесть алтын полшесты денги. Росписка дана»; «Деревни Любятина с трех осмаков с крохою февраля в 20 день принято у зборщика Артамона Дмитриева два рубли четыре алтына полторы денги»; «Деревни Крюкова с трех крох марта в 3 день принято у Ивана Иванова четырнатцать алтын полтретьи денги. Росписка дана. За пустотою не взято 2 алтына 5 денег» ${ }^{50}$.

В вотчинах данной духовной корпорации «кроха» и «полкрохи» являлись довольно распространенным тяглом дворов, где жила и хозяйствовала малая крестьянская семья. Так, 7 февраля 1724 г. Федор Тимофеев, крестьянин из деревни Пристанина Рузского уезда, подтверждал при свидетелях: «Здал я тяглой свой жеребей полкрохи и с пожитками своими и 3 детми своими, с сыном и $з$ дочерью своею, для того, что я овдовел третью женою, а здал я свояку своему села Покровское Агапу Потапову... А отдал я ему, Агапу,

\footnotetext{
${ }^{48}$ Там же. Д. 131.

${ }^{49}$ РГАДА. Ф. 1192. Оп. 3. 1721 г. Д. 11. Л. 16, 29.

${ }^{50}$ Там же. 1722 г. Д. 48. Л. 1-7.
} 
на десять лет» ${ }^{51}$. О том, что «кроха» дробилась на более мелкие доли, свидетельствуют крестьянские «скаски» о пустых тяглых жребиях, поданные в январе 1722 г. Например, в деревне Родионова зафиксирована «пустая долька без четверти кроха, что владел Егор Михайлов, а покинул де он, Егорей, тое дольку впусте от скудости своей». В деревне Чаща «полторы крохи» Самойлы Михайлова «запустело в 1721 году для того, что он, Самойла, монастырю не крепок, и его выслали за помещика». В деревне Чеклеева впусте полторы крохи Ивана Кузмина, который «з женою и 3 детми своими сшел неведомо куды». В деревне Никольская как пустое тягло записано шесть «покинутых» 1/3 долей «крохи» («А покинули де они, вышеписанные крестьяне, те свои тягла впусте от скудости своей и за одиночеством для того, что де ныне у них ерового хлеба нету и сеять и государевых податей платить стало нечем»). В селе Шестаково в «скасках» зафиксировано «впусте» тягло «полкрошки» Степана Захарова, в деревне Кондратово «полполкрошки» Прокофия Степанова ${ }^{52}$.

Последние записи свидетельствуют, что известная нам по дмитровским владениям Донского монастыря и деревням Федоровского монастыря в уезде Переславля Залесского лексема «крошка» использовалась и в вотчинах Иосифо-Волоколамского монастыря. О том, что понятия «кроха» и «крошка» выступают здесь как равнозначные, свидетельствует, например, челобитная, поданная в 1724 г. крестьянином деревни Медведкова Рузского уезда Аврамом Ивановым: «Тягла подо мной крошка с шестою долею крошки, а за саседом моим, Иваном Петровым, кроха без шестой доли» ${ }^{53}$. Следует также подчеркнуть, что в данной общине обе лексемы нередко употреблялись наряду с традиционными долями выти. Так, в упомянутых выше «скасках» 1722 г. как запустевшие в 1721 г. отмечены четыре «пустые дольки полчетверти осмака» крестьян деревни Родионова. При этом Афонасий Федоров сложил с себя это тягло «на весне за скудостью своею, а себе де он оставил тягла и живет в той деревне Родионове на полукрохе», а Петр Дементьев, отказавшийся от той же «полчетверти» «в прошлом 721 году на весне за скудостью своею», живет в той деревне Родионове на «получетверти осмака» ${ }^{54}$.

Система вытного тяглообложения как инструмент, с помощью которого община выполняет свою поземельно-фискальную функцию, продолжала существовать и после введения подушной подати. Так, крестьяне Иосифо-Волоколамского монастыря из деревни Ефремова Волоцкого

\footnotetext{
${ }^{51}$ Там же. 1724 г. Д. 20. Л. 10.

${ }^{52}$ Там же. 1722 г. Д. 33.

${ }^{53}$ Там же. 1724 г. Д. 20. Л. 34.

${ }^{54}$ Там же. 1722 г. Д. 33.
} 
уезда в 1724 г. сообщали в челобитной, что «пашни у нас в деревне только пять крох и с пустотою. И нам в таких лишних платежах и могуты не стало». «Пустота» возникла из-за соседей, которые покинули деревню, живут «в розных местах и кормятца в наймех», но подушную подать со своей общиной не платят. Однако в челобитной описан и уже знакомый нам сюжет. Крестьянин Дорофей Иванов попытался «сложить» с себя часть тягла: «Умыслом своим покидает доли своей половину крохи, на нас же уваливает. А сам толко хочет быть на полукрохе. И то он собою, а мы так разоряемся». Данный случай интересен тем, что в источнике приведены аргументы, которые деревенская община приводит для объяснения своего отказа уменьшить тягло: «А ему, Дорофею, возможно и всею долею своею владеть, понеже у него лошедь и скотина есть, и работать есть кому» ${ }^{55}$.

В том же 1724 г. крестьяне деревни Чеклеева Рузского уезда Алексей Степанов, Василий Ефремов, Иван Фатеев, Митрофан Федоров, Василий Петров, Григорий Макаров и Михаил Фадеев написали в своей челобитной: «Тягла под нами малое число, а детей мужеска полу много... За мною, за Алексеем, полторы крохи, а платил с шести душ. А за мною, Василием, кроха, а платил за четыре души. А за мною, Иваном, кроха, а платил за четыре души. А за мною, Митрофаном, треть полуосмака, а платил за четыре души. А за мною, Василием, кроха, а платил за три души. А за мною, Григорием, кроха, а платил за пять душ. А за мною, Михаилом Фадеевым, треть осмака, а платил с пяти душ». Они настаивали на необходимости «в том подушном окладе землею поверстатца против подушных наших платежей» с соседями, поскольку в той же деревне два двора сидят на тягле в 1,5 крохи и платят с 4 д. м. п., пять дворов на «крохе» платят с 2 д. м. п., еще один двор на трети полуосмака - с 1 д. м. П. При работоспособном крестьянском самоуправлении монастырь-землевладелец, как правило, не вмешивался в мирские процедуры, связанные с организацией уплаты государственных налогов и владельческих платежей, а также выполнением натуральных повинностей. 18 июня на челобитной появилась резолюция монастырских властей, разрешающая «учинить вам в земле равенство, поверстатца безобидно против душ» ${ }^{56}$. Впрочем, довольно скоро в крестьянских общинах в монастырских владениях Центра России возник и противоположный тренд, суть которого заключалась в возврате к прежней системе, учитывающей при наделении землей не число душ мужского пола, а реальную тяглоспособность двора. Л.Н. Вдовина, изучая общину на материалах монастырских архивов первой

\footnotetext{
55 Там же. 1724 г. Д. 29. Л. 1-1 об.

${ }^{56}$ Там же. 1724 г. Д. 20. Л. 16-17.
} 
половины XVIII в., пришла к выводу, что использовавшиеся как окладные единицы выть и ее доли (осмак, полуосмак, кроха и т. д.) «начинают исчезать» к середине столетия ${ }^{57}$.

\section{Литература}

Александров В.А. Сельская община в России (XVII - начало XIX в.). М., 1976.

Вдовина Л.Н. Крестьянская община и монастырь в Центральной России в первой половине XVIII в. М., 1988.

Горская Н.А. Монастырские крестьяне Центральной России в XVII в. М., 1977.

Назаров В.Д., Тихонов Ю.А. Крестьянский и бобыльский двор в светских владениях центральных уездов I половины XVII в. // История СССР. 1977. № 4. С. 152-162.

Словарь русского языка XI-XVII вв. Вып. 8. Крада - Лящина. М., 1981.

Словарь русского языка XVIII века. Вып. 11. Крепость - Льняной. СПб., 2000.

Соколова Н.В. Община в монастырской деревне Центра России в начале XVIII в. (К вопросу о поземельно-хозяйственной функции крестьянского мира) // Ежегодник по аграрной истории Восточной Европы. 2012 год: Типология и особенности регионального агарного развития России и Восточной Европы X-XXI вв. М.; Брянск, 2012. С. 91-104.

Соколова Н.В. Окладные книги как источник для изучения социальных микроструктур нижегородской монастырской деревни 60-90-х гг. XVII в. // Лествица: Материалы научной конференции по проблемам источниковедения и историографии памяти В.П. Макарихина. Нижегородский государственный университет (22 мая 2003 г.). Н. Новгород, 2005. С. 217-228.

Соколова Н.В. Роль крестьянской общины в системе налогово-повинностных практик XVII - первой четверти XVIII в. (на материалах монастырских вотчин Центральной России)//Ежегодник по аграрной истории Восточной Европы. 2014 год. Фискальная политика и налогово-повинностные практики в аграрной истории России X-XXI вв. М.; Самара, 2015. С. 65-76.

Соколова Н.В. Социальные микроструктуры монастырской деревни в Центральной России конца XVII - первой четверти XVIII в. (Некоторые источники и методы исследования) // Северо-Запад в аграрной истории России: Межвузовский тематический сборник научных трудов. Калининград, 2005. С. 12-26.

Черкасова М.С. Зажиточные крестьяне Троице-Сергиева монастыря в конце XVI XVII в.: тягло, наделы, денежная рента// Зажиточное крестьянство России в исторической ретроспективе. Материалы XXVII сессии Симпозиума по аграрной истории Восточной Европы. Вологда, 2001. С. 74-85.

Шапиро А.Л. Переход от повытной к повенечной системе обложения крестьян владельческими повинностями // Ежегодник по аграрной истории Восточной Европы. 1960 год. Киев, 1962. С. 207-217.

${ }^{57}$ См.: Вдовина Л.Н. Крестьянская община и монастырь в Центральной России в первой половине XVIII в. М., 1988. С. 77-78. 